\title{
Biophysical dissection of the antigen-antibody interaction of the broadly reactive anti-V3 human $\mathrm{mAb}$ 447-52D
}

\author{
A Killikelly ${ }^{1 *}$, H Zhang $^{1}$, B Spurrier ${ }^{1}$, C Williams², MK Gorny², S Zolla-Pazner ${ }^{2}$, X Kong ${ }^{1}$ \\ From AIDS Vaccine 2012 \\ Boston, MA, USA. 9-12 September 2012
}

\section{Background}

The immunogenic third variable region (V3) of HIV-1 gp120 is a target for AIDS vaccines. V3 is recognized by $\mathrm{mAb}$ 447-52D, known for its ability to neutralize viruses with a GPGR beta turn motif at the apex of V3, which is characteristic of clade B viruses. Interestingly, 447-52D can also bind non-clade B V3 peptides containing a GPGQ motif. A detailed biochemical and biophysical dissection of the antigen-antibody interaction of 447-52D was undertaken to understand this disparity.

\section{Methods}

We cloned and produced large amounts of the Fv fragment of 447-52D and a panel of mutations. We then measured their epitope binding characteristics by Isothermal Titration Calorimetry (ITC).

\section{Results}

We assessed the Fv-V3 binding by ITC for the following mutations in residues of the $\mathrm{mAb}$ that are thought to mediate three key interactions: (i) $\mathrm{Y}^{\mathrm{H} 100 \mathrm{j}}$ of the heavy chain $(\mathrm{H})$ to $\mathrm{T}\left(\mathrm{Y}^{\mathrm{H} 100 \mathrm{j}} \mathrm{T}\right)$ or $\mathrm{Y}^{\mathrm{H} 33} \mathrm{~A}$. These two aromatic residues form a pi-cation interaction, sandwiching the side chain of $\mathrm{R}^{315}$ of the GPGR motif in the V3-peptide. These mutations reduce binding affinity by 56 and 171fold, respectively. (ii) $\mathrm{W}^{\mathrm{L} 91}$ of the light chain (L) to A $\left(\mathrm{W}^{\mathrm{L} 91} \mathrm{~A}\right)$. This residue packs against $\mathrm{P}^{313}$ of the $\mathrm{V} 3$ GPGR turn. This mutation reduces binding 230-fold. (iii) $D^{H 95} R$ of the heavy chain or $R^{315} \mathrm{Q}$ of the epitope. These two residues form a salt bridge between the antigen and the antibody. These mutations reduce binding by 224 and 171-fold, respectively. These data suggest a hierarchy

${ }^{1}$ New York University Medical Center, New York, NY, USA

Full list of author information is available at the end of the article of interactions and the salt bridge plays an important role in the affinity.

\section{Conclusion}

$\mathrm{mAb}$ 447-52D binds non-clade B peptides with the R315Q variation with much less affinity, explaining why it cannot neutralize non-clade B viruses. Through probing specific contributions of individual residues by mutagenesis and ITC, we were able to fully characterize the interactions between V3 and 447-52D.

\section{Author details}

${ }^{1}$ New York University Medical Center, New York, NY, USA. ${ }^{2}$ Veterans Affairs New York Harbor Healthcare System, New York, NY, USA.

Published: 13 September 2012

doi:10.1186/1742-4690-9-S2-P67

Cite this article as: Killikelly et al:: Biophysical dissection of the antigenantibody interaction of the broadly reactive anti-V3 human mAb 44752D. Retrovirology 2012 9(Suppl 2):P67.

Submit your next manuscript to BioMed Central and take full advantage of:

- Convenient online submission

- Thorough peer review

- No space constraints or color figure charges

- Immediate publication on acceptance

- Inclusion in PubMed, CAS, Scopus and Google Scholar

- Research which is freely available for redistribution 